\title{
RANCANG BANGUN SISTEM DISTRIBUSI HASIL PRODUKSI OBAT UNTUK MENJAMIN KUALITAS DALAM MENINGKATKAN PELAYANAN PELANGGAN
}

\author{
Turki Salim ${ }^{1}$, Muhamad Yusup*², Dewi Listiani Sukamto ${ }^{3}$ \\ ${ }^{1,2,3}$ Program Studi Teknik Informatika Universitas Raharja \\ Email : ${ }^{1}$ turkisalimbaras@ raharja.info, ${ }^{* 2}$ yusup@ raharja.info, ${ }^{3}$ listiani @ raharja.info
}

\begin{abstract}
Abstraksi
Perusahaan farmasi di Indonesia yang bergerak dalam bidang manufaktur saat ini terus mengalami perkembangan, mereka mengolah bahan obat menjadi bahan obatan-obatan, sepeti tablet, syirup, kapsul dan lain-lain. Pada saat ini sistem manajemen distribusi dan produksi obat masih bersifat semi komputerisasi, karena masih menggunakan Ms. Excel, yang dapat menyebabkan terjadinya penumpukan berkas-berka, selain itu dimungkinkan data-data tersebut akan hilang atau rusak, dan ketika dilakukan pencarian data-data, membutuhkan waktu yang cukup lama lama. Untuk mengatasi hal tersebut perlu dibangun sebuah sistem untuk mengolah sistem manajemen distribusi dan produksi obat, untuk membantu perusahaan agar lebih mudah mengakses data-data obat sampai surat jalan secara terkomputerisasi, sehingga dapat meningkatkan efektifitas dan efesien waktu, serta mendapatkan hasil kerja maksimal dan keakuratan data dalam input data pada bagian yang bersangkutan. Hal tentunya dapat dicapat dengan berbagai metode yang penulis gunakan, mulai dari penggunaan uml untuk memberikan gambaran rancangan sistem, kemudian MySql sebagai aplikasi pengolah data pada database, sebagai bahasa pemrograma nmenggunakan php.
\end{abstract}

Kata kunci: Distribusi, Hasil Produksi Obat, Kualitas

\begin{abstract}
Pharmaceutical companies in Indonesia that are engaged in manufacturing currently continue to develop, they process medicinal ingredients into pharmaceuticals, such as tablets, syrup, capsules and others. At present the distribution and production management system of drugs is still semi-computerized, because it still uses Ms. Excel, which can cause file-to-file buildup, besides that it is possible that the data will be lost or damaged, and when searching for data, it takes a long time. To overcome this need to be built a system to process the drug distribution and production management system, to help companies more easily access drug data to computerized travel documents, so as to increase the effectiveness and time efficiency, and get maximum work results and data accuracy in data input in the relevant section. It certainly can be found with various methods that use penuls, starting from the use of uml to provide an overview of system design, then MySql as a data processing application in the database, as a programming language using php.
\end{abstract}

Keywords: Distribution, Drug Production Results, Quality

\section{PENDAHULUAN}

Seiring perkembangan ilmu farmasi yang semakin terus berkembang diharapkan dapat menerapkan CPOB (Cara Pembuatan Obat yang Baik) yang meliputi pengawasan mutu, manajemen mutu, produksi, higienis, dokumentasi, ketentuan umum, inspeksi diri dan audit mutu, serta penanganan keluhan terhadap obat, pembuatan dan analisis berdasarkan kontrak, 
kualifikasi dan validasi [7]. Pembangunan sarana distribusi hasil produksi farmasi adalah sebagai salah satu upaya pembangunan nasional yang diarahkan guna untuk mencapai terpenuhinya kebutuhan ketersediaan farmasi yang tepat dan untuk menjamin kualitas produk [8].

Pada saat ini sistem proses produksi obat masih bersifat semi komputerisasi. Jumlah seluruh data yang ada di bagian produksi obat tidak sedikit, hal ini memungkinkan adanya penumpukan berkas-berkas dan kemungkinan data-data tersebut akan hilang atau rusak, sehingga ketika ingin mencari data-data tersebut membutuhkan waktu yang lama, bahkan terkadang hal ini mempengaruhi kualitas hasil produksi. Untuk mengatasi hal tersebut maka dibutuhkan adanya sistem yang akan mengolah data proses produksi obat. Dengan sistem ini maka diharapkan dapat bermanfaat dan dapat mempermudah dalam melakukan pencatatan data serta mempermudah dalam mencari data tertentu dengan lebih mudah dan cepat.

Suatu sistem yang terotomatisasi dapat membantu petugas dalam menyelesaikan kewajibanya dangan lebih cepat sehingga mengurangi tingkat keterlambatan yang akan mengganggu stabilitas perusahaan[1][9].Distribusi artinya proses yang menunjukkan penyaluran barang dari produsen sampai ke tangan masyarakat konsumen. Produsen artinya orang yang melakukan kegiatan produksi. Konsumen artinya orang yang menggunakan atau memakai barang/jasa dan orang yang melakukan kegiatan distribusi disebut distributor[2][10]Produksi adalah kegiatan atau proses menghasilkan, menyiapkan, mengolah, membuat, mengemas, dan/atau mengubah bentuk sediaan farmasi dan alat kesehatan.

Kebutuhan akan suatu sistem komputerisasi pada zaman sekarang ini mencakup kesegala bidang yang berhubungan dengan penerapan teknologi informasi. Setiap perusahaan swasta maupun pemerintahan sangat membutuhkan sistem komputerisasi yang relevan, akurat, cepat, dan efisien [3] Ketersediaan informasi yang cepat dan akurat serta didukung dengan penerapan sistem yang optimal menjadi kelebihan sendiri harus dimiliki setiap perusahaan [4][12]Perancangan Sistem adalah suatu kegiatan membuat desain teknis berdasarkan kegiatan pada waktu proses analisis. Perancangan disini dimaksudkan suatu proses pemahaman dan peran suatu sistem informasi berbasis komputer. [5][16] Monitoring adalah kegiatan memantau yang dilakukan secara rutin mengenai kemajuan project yang sedang berjalan atau kegiatan memantau perubahan proses dan output project.[6][17].

\section{METODE PENELITIAN}

Metode penelitian merupakan suatu tata cara atau kegiatan pelaksanaan penelitian rangka untuk mengumpulkan informasi atau data serta melakukan investigasi terhadap data yang telah didapatkan tersebut. yang didasari oleh asumsi-asumsi dasar, pandangan-pandangan filosofis dan ideologis, pertanyaan dan isu-isu yang dihadapi [18]. Suatu penelitian mempunyai rancangan penelitian tertentu. Rancangan ini menggambarkan prosedur atau langkah-langkah yang harus ditempuh, waktu penelitian, sumber data dan kondisi arti untuk apa data dikumpulkan dan dengan cara bagaimana data tersebut dihimpun dan diolah untuk dianalisa dalam pembuatan laporan [11][19].

\subsection{Metode Observasi (Observasi Research)}

Pada tahapan ini penulis melakukan pengamatan langsung dari objek penelitian untuk mendapatkan data dan informasi yang akurat dan lengkap dari berbagai pihak yang terkait dan berhubungan dengan tema penelitian yang berhasil penulis rumuskan.

\section{a. $\quad$ Metode Wawancara (Interview Research)}

Penulis melakukan wawancara produksi obat yang mengolah data obat dan produksi, penulis mendapatkan informasi berkaitan dengan penelitian penulis. 


\section{b. $\quad$ Metode Studi Pustaka (Studi Literature)}

Selain melakukan observasi penulis juga melakukan data dengan cara studi pustaka dalam metode ini penulis berusaha untuk melengkapi data-data yang diperoleh dengan membaca dan mempelajari dari buku-buku dan data-data yang relevan. Buku dan data tersebut digunakan penulis untuk membantu penganalisaan dan perancangan yang dilakukan.

\subsection{Metode Analisis Data}

Pada penelitian ini, metode analisa dilakukan dengan langkah-langkah melakukan pengamatan dan analisa terhadap sistem yangberjalan saat ini, serta menentukan UML (Unified Modeling Language) yang meliputi use case diagram, activity diagram, sequence diagram.

\section{PEMBAHASAN}

Untuk dapat menggambarkan prosedur secara keseluruhan diperlukan bebrapa tahapan analisa sebagai bentuk pengumpulan informasi guna mendapatkan model yang sesuai dengan kebutuhan dan mampu memberikan solusi dengan cepat secara efektif dan efisien, mulai dari tahapan pengumpulan informasi dan kebutuhan, analisa dokumen, merancangan hubungan antar dokumen sampai dengan merancanga model diagram database dan model rancangan sistem [20]. Beberapa tahapan yang dimaksud sampai dengan model ranangan yang diciptakan dapat dilihat pada gambar 1,2,3,4,5.

\subsection{Use Case Diagram Prosedur Berjalan}

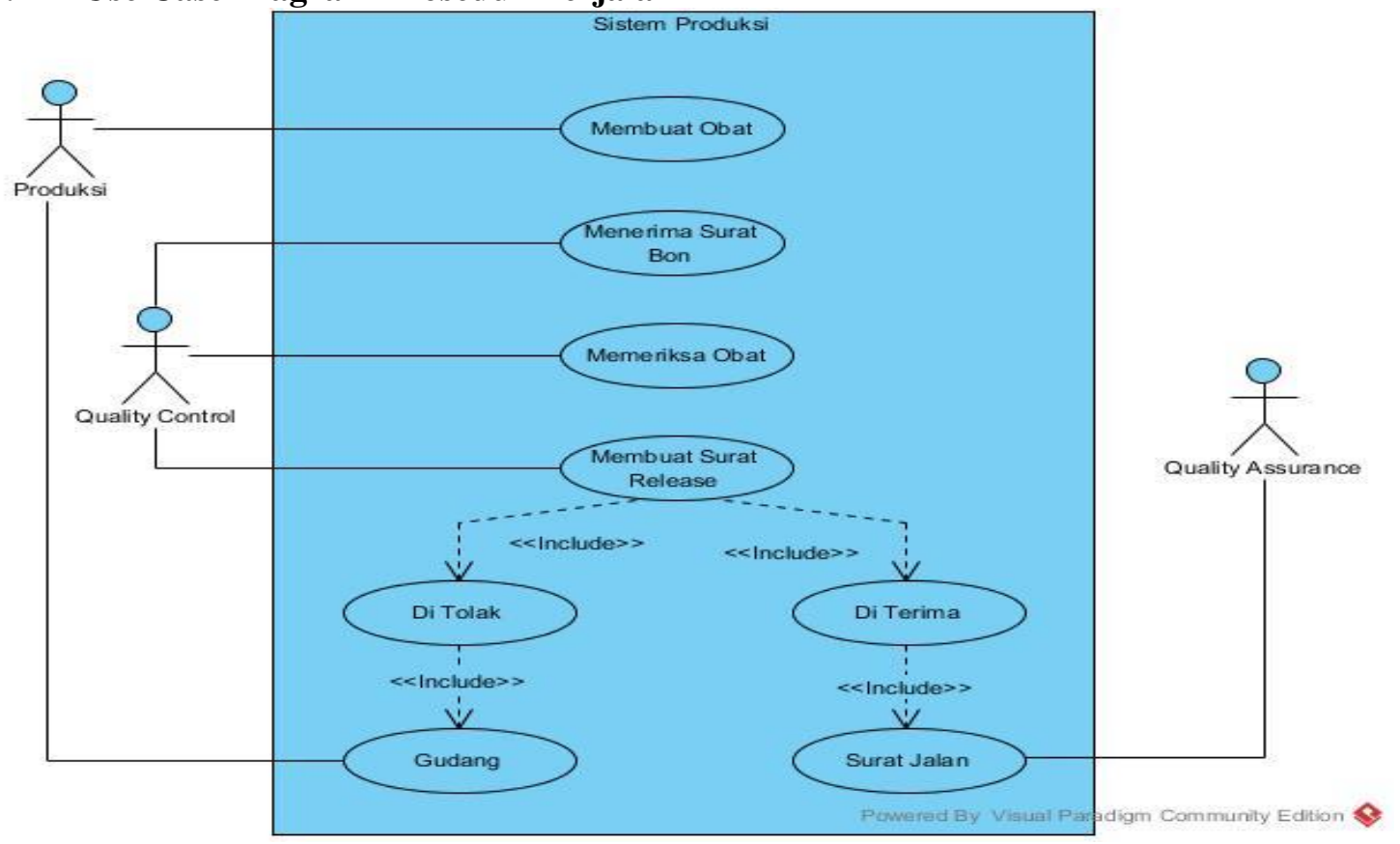

Gambar 1. Use Case Diagram Berjalan

Berdasarkan gambar use case Diagram (gambar 1) yang berjalan saat ini sistem yang mencakup seluruh kegiatan pada sistem sistem manajemen distribusi dan produksi obat. Terdapat 3 (tiga) Actor yang melakukan kegiatan yaitu produksi, quality control, dan quality assurance yang berfungsi membuat order, menerima surat bon, memeriksa obat, membuat surat release, di tolak, gudang, di terima, dan suratjalan.

Terdapat juga 8 (delapan) use case yangmerupakan proses yang terjadipada sistem berjalan yaitu membuat obat yang melibatkan produksi, menerima surat bon, memeriksa obat, membuat surat release, di tolak dan di terima yang melibatkan quality control, gudang yang melibatkan produksi, dan surat jalan yang melibatkan quality assurance. 


\subsection{Activity Diagram Prosedur Berjalan}

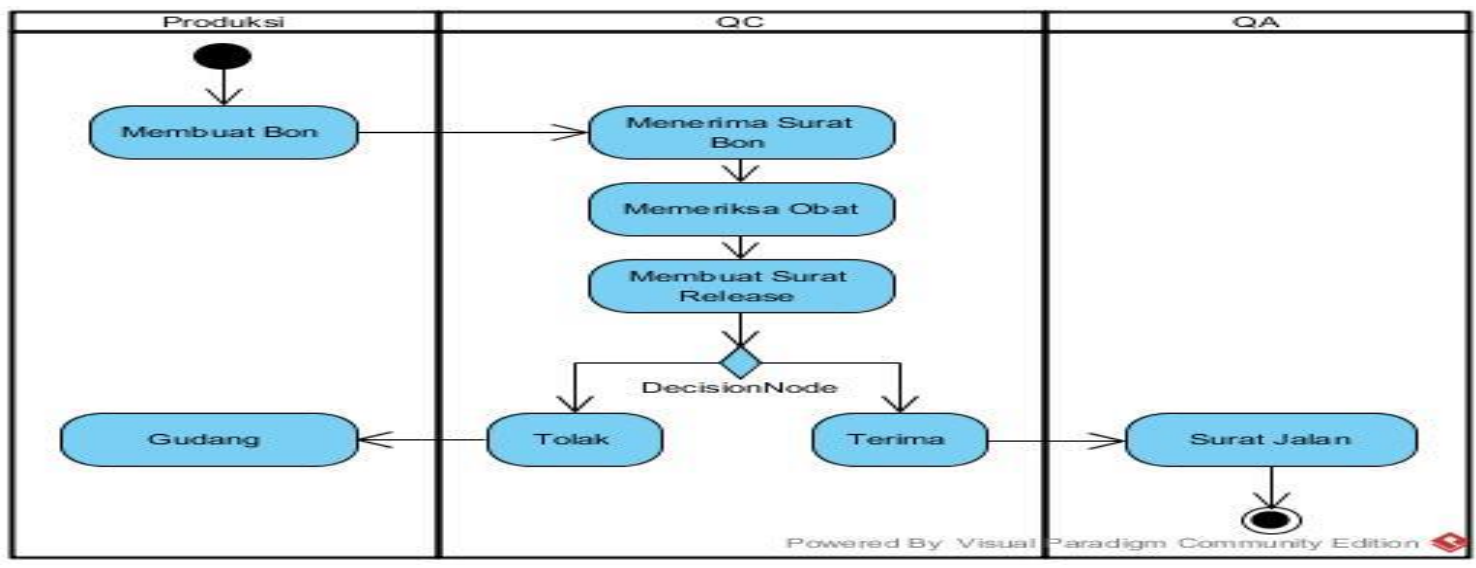

Gambar 2. Activity Diagram Berjalan

Berdasarkan gambar activity diagram (gambar 2) yang berjalan saat ini sistem mencakup seluruh kegiatan sistem manajemen distribusi dan produksi obat.Sistem ini melibatkan 3 (tiga) Actor yaitu, produksi yang menangani membuat bon dan gudang, kemudian menerima surat bon, memeriksa obat, membuat surat release, di tolak, dan di terima yang dilakukan oleh quality control, kemudian surat jalan yang dilakukan quality assurance.

\subsection{Sequence Diagram Prosedur Berjalan}

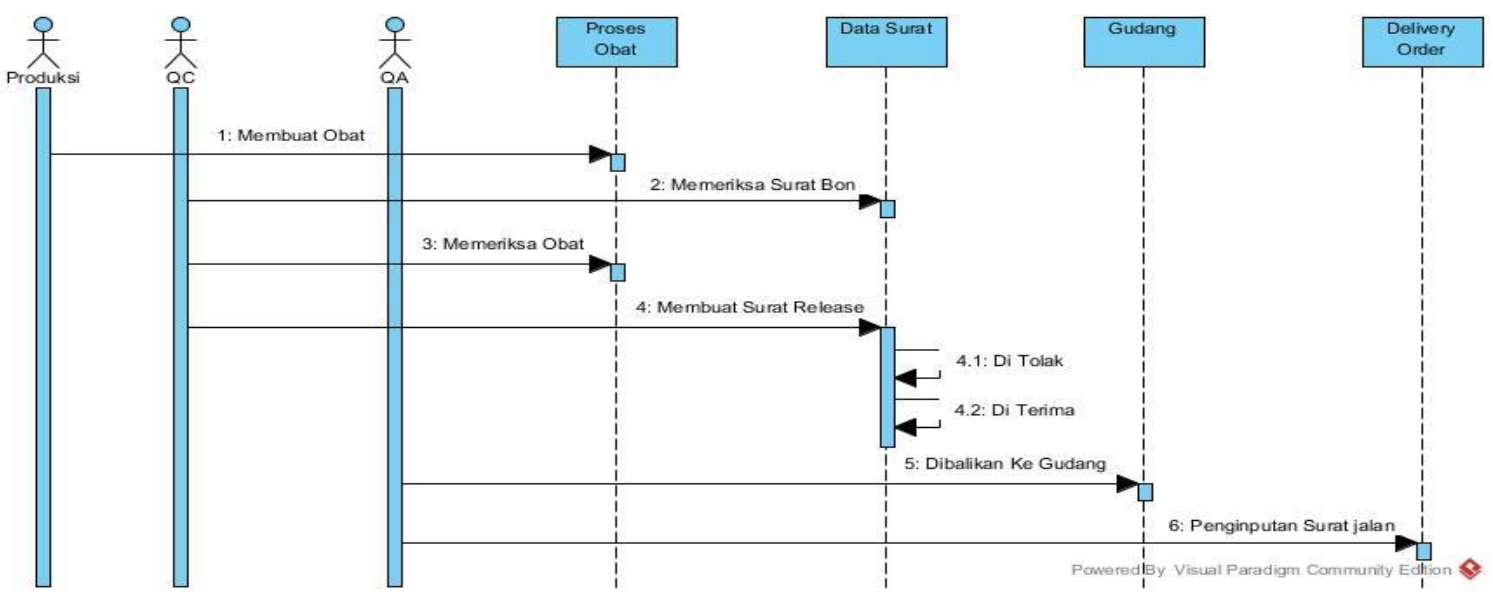

Gambar 3. Squence Diagram Berjalan

Berdasarkan gambar sequence diagram (gambar 3) yang berjalan saat ini terlihat 3 (tiga) actor yang melakukan kegiatan diantaranya: produksi, quality control, dan quality assurance, yang akan menyelesaikan 8 message yaitu, membuat obat, memeriksa surat bon, memeriksa obat, membuat surat release, di tolak, di terima, dibalikan kegudang, dan penginputan surat jalan.

Rancangan diatas (gambar 1, 2, 3) merupakan gambaran prosedur yang berjalan dimana pada tahapan ini melibatkan beberapa dokumen seperti membuat bon, periksa obat, membuat surat release. Dimana membuat obat dibuat oleh produksi yang berfungsi untuk mengetahui obat apa saja yang akan di pesan dan jumlahnya. Periksa obat yang dibuat oleh quality control yang befungsi untuk mengetahui apakah ada obat yang reject atau tidak dan tanggal kadaluarsa. Membuat surat release dibuat oleh quality assurance yang berfungsi untuk mengetahui apakah ada obat yang reject atau tidak. 


\subsection{Class Diagram}

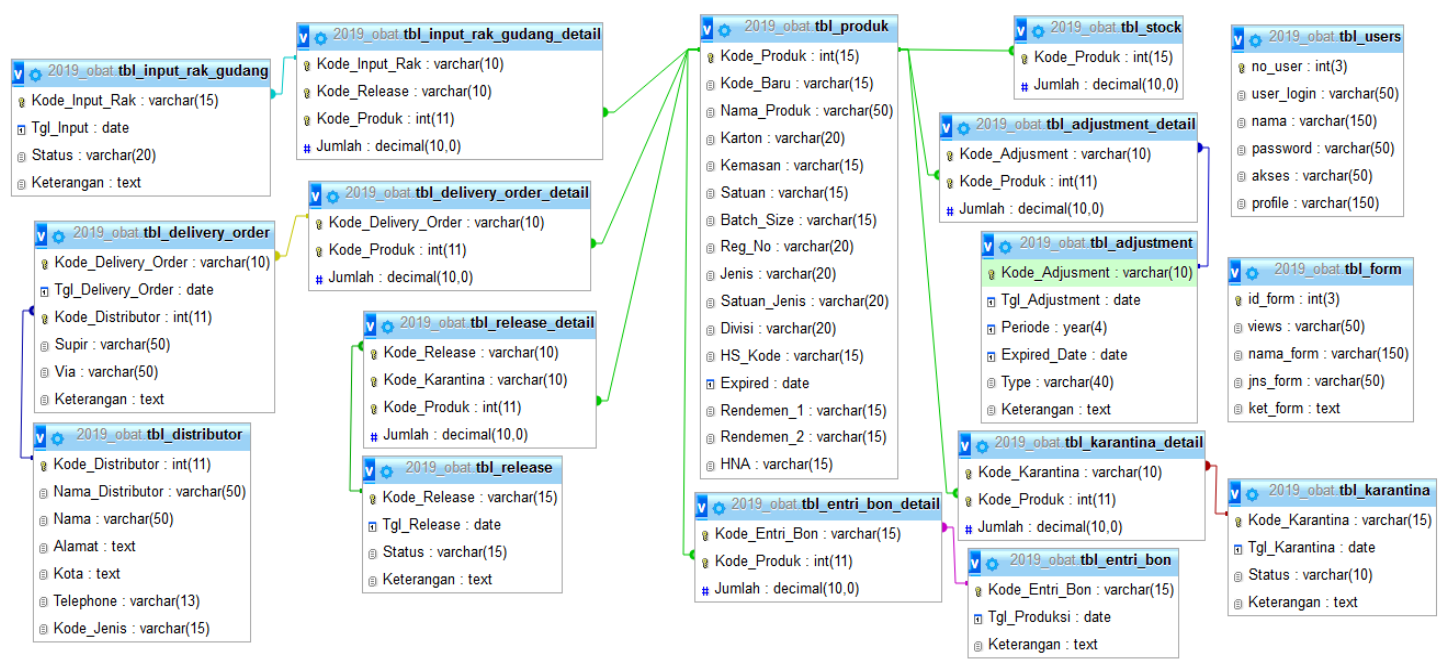

Gambar 4. Class Diagram

Bedasarkan gambar class diagram (gambar 4) yang berjalan saat ini sistem yang mencakup seluruh kegiatan pada sistem manajemen distribusi dan produksi obat. Terdapat 17 (tujuh belas) class yaitu, produk, distributor, users, dan form yang merupakan tabel master, entri_bon, adjustment, karantina, release, input_rak_gudang, dan delivery_order sebagai table transaksi, serta table detail_sj yang tercipta karena adanya tbl_entri_bon_detail, tbl_adjustment_detail, tbl_karantina

Berdasarkan gambar class diagram (gambar 4) yang berjalan saat ini sistem yang mencakup seluruh kegiatan pada sistem pelaporan hutang dagang. Terdapat 10 (sepuluh) class yaitu user, barang, supplier yang merupakan tabel master dan po, surat_jalan, invoice, faktur_pajak, tanda_terima_invoice sebagai tabel transaksi, serta tabel detail_sj yang tercipta karena adanya tabel surat_jalan, tabel detail_po yang tercipta karena adanya tabel po dan merupakan tabel histori.

Berdasarkan gambar class diagram (gambar 4) diatas dapat dilihat dengan jelas bahwa tingkat hubungan po dan surat_jalan yaitu one to many (1:M), tingkat hubungan supplier dan po one to many $(1: \mathrm{M})$, tabel detail_po tercipta karena adanya tingkat hubungan many to many (M:M) antara tabel podan tabel barang.tabel detail_sj tercipta karena adanya tingkat hubungan many to many (M:M) antara tabel barang dan tabel surat_jalan. Tingkat hubungan user dan po yaitu one to many (1:M). Tingkat hubungan surat_jalan dan invoice yatu many to one (M:1), tingkat hubungan invoice danfaktur_pajak yaitu one to one (1:1). Tingkat hubungan faktur_pajak dantanda_terima_invoice yaitu one to one (1:1).

\subsection{Use Case Diagram Usulan}




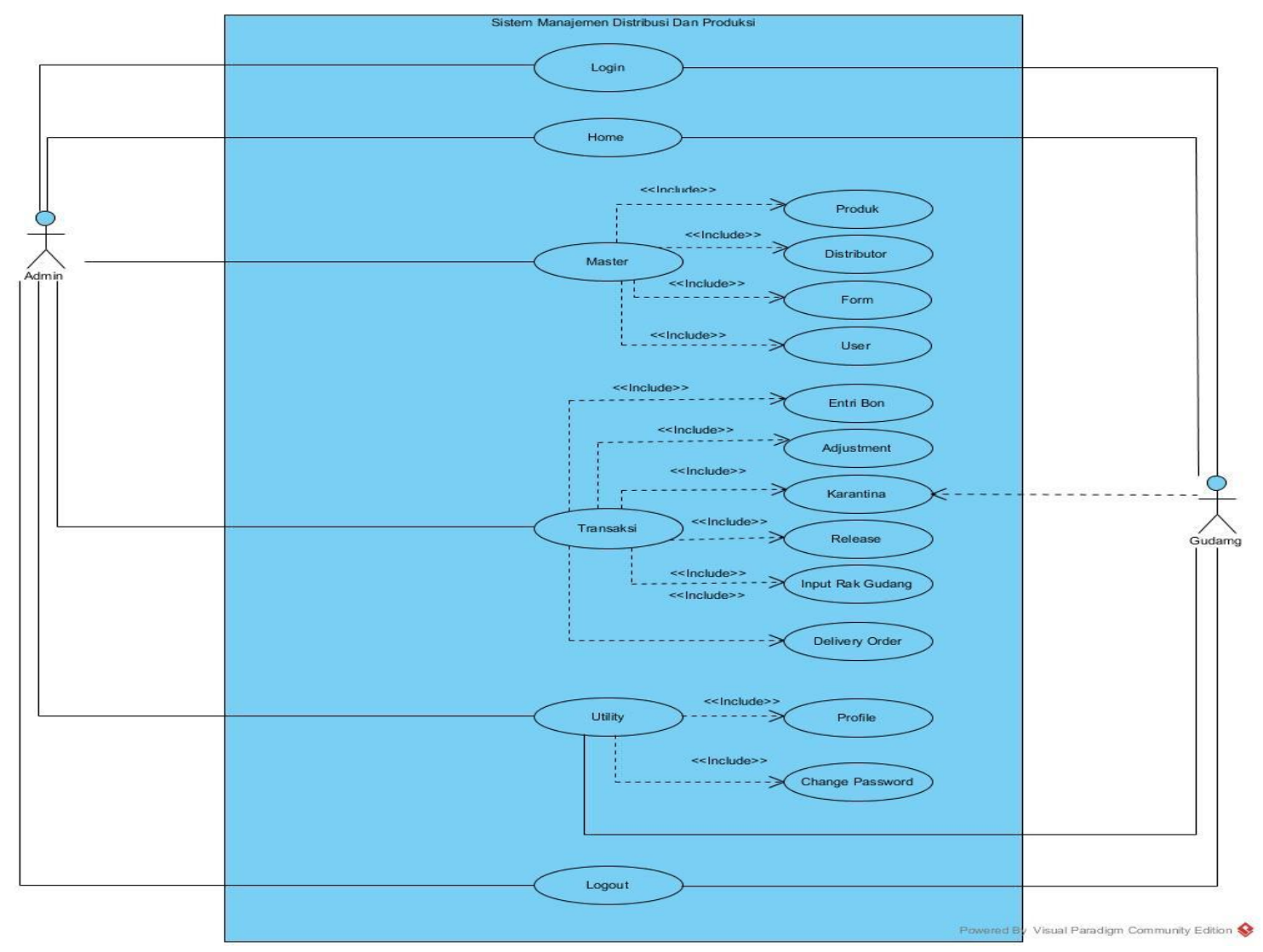

Gambar 5. Use Case Diagram Usulan

Berdasarkan gambar use case diagram usulan (gambar 5) terlihat jelas bahwa terdapat 18(delapan belas) use case yang terdiri dari 5 (lima) use case utama yaitu login, home, master, transaksi, laporan. Use case master memiliki 4 (empat) yang terdiri dari user yang terhubung dengan actor user, barang, supplier berhubungan dengan actor user dan actor supplier. Use case transaksi memiliki 4 (empat) yang terdiri dari po, surat jalan, invoice, tanda terima invoice, yang terhubung dengan actor user dan supplier.Use case report memiliki 4 (empat) yang terdiri dari hutang ke supplier, jatuh tempo hutang, presentasi jatuh tempo, estimasi pembayaran yang terhubung dengan actor user dengan pimpinan.

Use diagram sebagai bentuk rancangan sistem yang akan diciptakan (gambar 5 dan 6) merupakan desain model tampilan utama yang berorintasi pada kebutuhan menu pada aplikasi yang disiapkan, selain itu untuk kebutuhan penyimpanan informasi data agar dapat digunakan secara histori juga digambarkan dalam bentuk class diagram (gambar 4) lengkap dengan informasi field dan type data sesuai kebutuhan penyimpanan data.

\subsection{IMPLEMENTASI}

\subsubsection{Rancangan Basis Data}

Untuk dapat menggamarkan bentuk basis data secara utuh, peneliti penggunakan aplikasi microsoft access sebagai bentuk gambaran dasar, dan pada akhirnya bentuk rancangan basis data ini dapat disesuaikan menggunakan apa saja sesuai kebutuhan.

a. Tabel Master: Produk

Primary Key : Kode_Produk

Foreign Key : : -

Structure Tabel : \{Kode_Produk, Kode_Baru, Nama_Produk, Karton, Kemasan, Satuan, 


\begin{tabular}{|c|c|c|c|c|c|c|c|c|}
\hline & \# & Nama & Jenis & Penyortiran & Atribut & Kosong & Bawaan & Ekstra \\
\hline$\square$ & 1 & Kode_Produk & $\operatorname{int}(15)$ & & & Tidak & Tidak ada & AUTO_INCREMENT \\
\hline$\square$ & 2 & Kode_Baru & $\operatorname{varchar}(15)$ & latin1_swedish_ci & & Ya & NULL & \\
\hline$\square$ & 3 & Nama_Produk & $\operatorname{varchar}(50)$ & latin1_swedish_ci & & Ya & NULL & \\
\hline$\square$ & 4 & Karton & varchar(20) & latin1_swedish_ci & & Ya & NULL & \\
\hline$\square$ & 5 & Kemasan & varchar(15) & latin1_swedish_ci & & Ya & NULL & \\
\hline$\square$ & 6 & Satuan & varchar(15) & latin1_swedish_ci & & Ya & NULL & \\
\hline$\square$ & 7 & Batch_Size & varchar(15) & latin1_swedish_ci & & Ya & NULL & \\
\hline$\square$ & 8 & Reg_No & varchar(20) & latin1_swedish_ci & & Ya & NULL & \\
\hline$\square$ & 9 & Jenis & varchar(20) & latin1_swedish_ci & & Ya & NULL & \\
\hline$\square$ & 10 & Satuan_Jenis & varchar(20) & latin1_swedish_ci & & Ya & NULL & \\
\hline$\square$ & 11 & Divisi & varchar(20) & latin1_swedish_ci & & Ya & NULL & \\
\hline$\square$ & 12 & HS_Kode & varchar(15) & latin1_swedish_ci & & Ya & NULL & \\
\hline$\square$ & 13 & Expired & date & & & Ya & NULL & \\
\hline$\square$ & 14 & Rendemen_1 & varchar(15) & latin1_swedish_ci & & Ya & NULL & \\
\hline$\square$ & 15 & Rendemen_2 & varchar(15) & latin1_swedish_ci & & Ya & NULL & \\
\hline 同 & 16 & HNA & varchar(15) & latin1_swedish_ci & & Ya & NULL & \\
\hline
\end{tabular}

Tabel 1.TabelProduk

\section{b. Tabel Master: Distributor}

Primary Key : Kode_Distributor

Foreign Key : :

Structure Tabel : \{ Kode_Distributor, Nama_Distributor, Nama, Alamat, Kota, Telephone,

\begin{tabular}{|c|c|c|c|c|c|c|c|c|}
\hline & $\#$ & Nama & Jenis & Penyortiran & Atribut & Kosong & Bawaan & Ekstra \\
\hline$\square$ & 1 & Kode_Distributor & int(11) & & & Tidak & Tidak ada & AUTO_INCREMENT \\
\hline$\square$ & 2 & Nama_Distributor & $\operatorname{varchar}(50)$ & latin1_swedish_ci & & Ya & NULL & \\
\hline$\square$ & 3 & Nama & varchar(50) & latin1_swedish_ci & & Ya & NULL & \\
\hline$\square$ & 4 & Alamat & text & latin1_swedish_ci & & Ya & NULL & \\
\hline$\square$ & 5 & Kota & text & latin1_swedish_ci & & Ya & NULL & \\
\hline$\square$ & 6 & Telephone & varchar(13) & latin1_swedish_ci & & Ya & NULL & \\
\hline$\square$ & 7 & Kode_Jenis & varchar(15) & latin1_swedish_ci & & Ya & NULL & \\
\hline
\end{tabular}

Tabel 2.Tabel Distributor

c. Tabel Master: Users

Primary Key : no_user

$\begin{array}{lll}\text { Foreign Key } & : & - \\ \text { Structure Tabel } & : & \text { nno user, user login, nama, password, akses, profile }\end{array}$

$\underset{\text { \# Nama }}{\text { Structure Tabel }} \underset{\text { Jenis }}{:}\left\{\right.$ no_user, user_login, $\underset{\text { Penyortiran }}{\text { Atribut }}$ Kosong ${ }_{\text {Bawaan }}$ Ekstra

\begin{tabular}{|c|c|c|c|c|c|c|c|}
\hline & $\#$ & Nama & Jenis & Penyortiran & Atribut & Kosong & Bawaan Ekstra \\
\hline$\square$ & 1 & no_user & $\operatorname{int}(3)$ & & & Tidak & Tidak ada AUTO_INCREMENT \\
\hline$\square$ & 2 & user_login & $\operatorname{varchar}(50)$ & latin1_swedish_ci & & Ya & NULL \\
\hline$\square$ & 3 & nama & varchar(150) & latin1_swedish_ci & & Ya & NULL \\
\hline$\square$ & 4 & password & $\operatorname{varchar}(50)$ & latin1_swedish_ci & & Ya & NULL \\
\hline$\square$ & 5 & akses & $\operatorname{varchar}(50)$ & latin1_swedish_ci & & Ya & NULL \\
\hline$\square$ & 6 & profile & varchar(150) & latin1_swedish_ci & & Ya & NULL \\
\hline
\end{tabular}

Tabel 3.Tabel Users

d. Tabel Master: Form

Primary Key : id_form

Foreign Key : : -

Structure Tabel $\quad: \quad\{$ id_form, views, nama_form, jns_form, ket_form $\}$ 


\begin{tabular}{|c|c|c|c|c|c|c|c|c|}
\hline & $\#$ & Nama & Jenis & Penyortiran & Atribut & Kosong & Bawaan & Ekstra \\
\hline$\square$ & 1 & id_form & int(3) & & & Tidak & Tidak ada & \\
\hline$\square$ & 2 & views & $\operatorname{varchar}(50)$ & latin1_swedish_ci & & Ya & NULL & \\
\hline$\square$ & 3 & nama_form & varchar(150) & latin1_swedish_ci & & Ya & $N U L L$ & \\
\hline$\square$ & 4 & jns_form & varchar(50) & latin1_swedish_ci & & Ya & NULL & \\
\hline$\square$ & 5 & ket_form & text & latin1_swedish_ci & & Ya & $N U L L$ & \\
\hline
\end{tabular}

Tabel 4. Tabel Form

e. Tabel Transaksi: Entri_Bon

Primary Key : : -

Foreign Key : Kode_Entri_Bon

Structure Tabel : \{ Kode_Entri_Bon, Tgl_Produksi, Keterangan

\begin{tabular}{|c|c|c|c|c|c|c|c|c|}
\hline & \# & Nama & Jenis & Penyortiran & Atribut & Kosong & Bawaan & Ekstra \\
\hline$\square$ & 1 & Kode_Entri_Bon & varchar(15) & latin1_swedish_ci & & Tidak & Tidak ada & \\
\hline$\square$ & 2 & Tgl_Produksi & date & & & Ya & NULL & \\
\hline$\square$ & 3 & Keterangan & text & latin1_swedish_ci & & Tidak & Tidak ada & \\
\hline
\end{tabular}

Tabel 5.TabelEntri Bon

f. Tabel Transaksi: Adjustment

Primary Key : Kode_Adjustment

Foreign Key : : -

Structure Tabel : \{ Kode_Adjustment, Tgl_Adjustement, Periode, Expired_Date, Type,

\begin{tabular}{|c|c|c|c|c|c|c|c|c|}
\hline & \# & Nama & $\begin{array}{l}\text { terangan }\} \\
\text { Jenis }\end{array}$ & Penyortiran & Atribut & Kosong & Bawaan & Ekstra \\
\hline$\square$ & 1 & Kode_Adjusment & varchar(10) & latin1_swedish_ci & & Tidak & Tidak ada & \\
\hline$\square$ & 2 & Tgl_Adjustment & date & & & Tidak & Trdak ada & \\
\hline$\square$ & 3 & Periode & year(4) & & & Tidak & Tidak ada & \\
\hline$\square$ & 4 & Expired_Date & date & & & Tidak & Tidak ada & \\
\hline$\square$ & 5 & Type & $\operatorname{varchar}(40)$ & latin1_swedish_ci & & Ya & NULL & \\
\hline$\square$ & 6 & Keterangan & text & latin1_swedish_ci & & Ya & NULL & \\
\hline
\end{tabular}

Tabel 6.Tabel Adjustment

g. Tabel Transaksi: Karantina

Primary Key

Foreign Key : Kode_Karantina

Structure Tabel $\quad: \quad$ KKode_Karantina, Tgl_Karantina, Status, Keterangan $\}$

\begin{tabular}{|c|c|c|c|c|c|c|c|c|}
\hline & $\#$ & Nama & Jenis & Penyortiran & Atribut & Kosong & Bawaan & Ekstra \\
\hline$\square$ & 1 & Kode_Karantina & varchar(15) & latin1_swedish_ci & & Tidak & Tidak ada & \\
\hline$\square$ & 2 & Tgl_Karantina & date & & & Ya & NULL & \\
\hline$\square$ & 3 & Status & $\operatorname{varchar}(10)$ & latin1_swedish_ci & & Ya & NULL & \\
\hline$\square$ & 4 & Keterangan & text & latin1_swedish_ci & & Ya & NULL & \\
\hline
\end{tabular}

Tabel 7.TabelKarantina

h. Tabel Transaksi: Delivery Order

Primary Key : Kode_Distributor

Foreign Key : Kode_Release, dan Kode_Produk

Structure Tabel : \{ Kode_Delivery_Order, Tgl_Delivery_Order, Kode_Distributor, Supir,

\begin{tabular}{|c|c|c|c|c|c|c|c|c|}
\hline & \# & Nama & Jenis & Penyortiran & Atribut & Kosong & Bawaan & Ekstra \\
\hline$\square$ & 1 & Kode_Delivery_Order & varchar(10) & latin1_swedish_ci & & Tidak & Tidak ada & \\
\hline$\square$ & 2 & Tgl_Delivery_Order & date & & & Tidak & Tidak ada & \\
\hline$\square$ & 3 & Kode_Distributor & int(11) & & & Tidak & o & \\
\hline$\square$ & 4 & Supir & varchar(50) & latin1_swedish_ci & & Ya & NULL & \\
\hline$\square$ & 5 & Via & varchar(50) & latin1_swedish_ci & & Ya & NULL & \\
\hline$\square$ & 6 & Keterangan & text & latin1_swedish_ci & & Ya & NULL & \\
\hline
\end{tabular}


Tabel8.Tabel Delivery Order

\subsection{Grafik SistemProduksiObat}

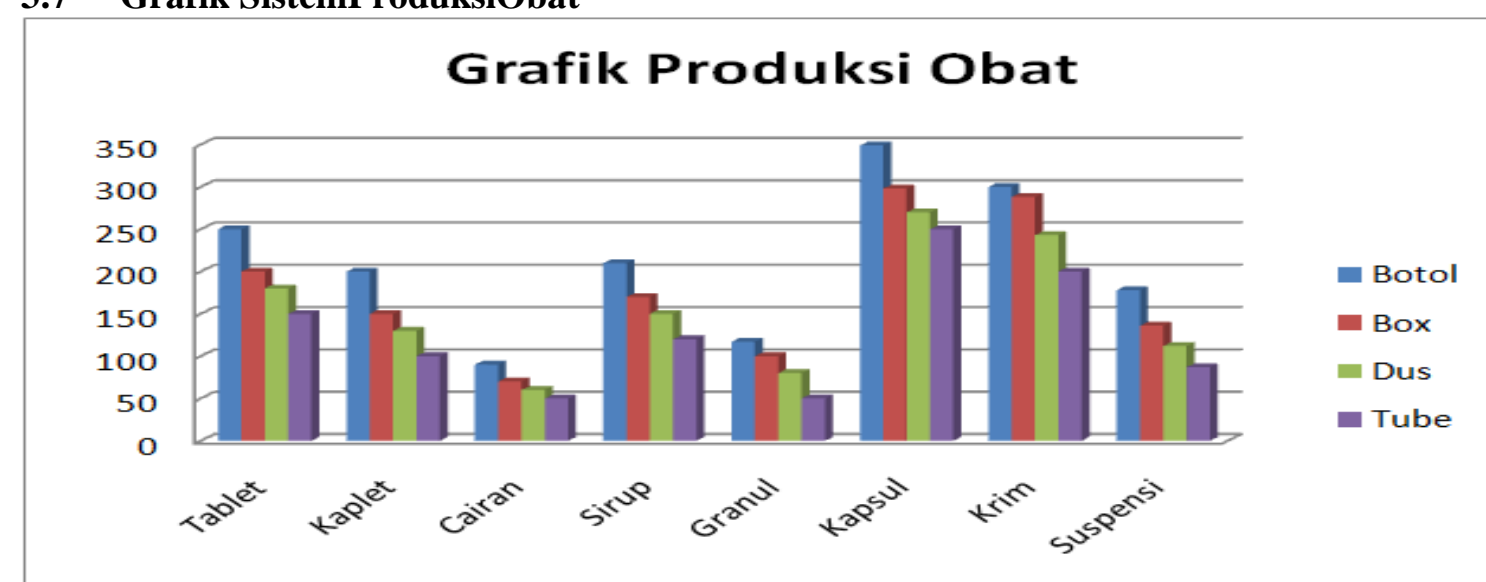

Gambar 6.SistemProduksiObat

Grafik diatas (gambar 6) merupakan grafik sistem produksi obat berdasarkan jenis obat dan kemasan. Grafik diatas bisa diambil berdasarkan Datewarehouse, sebagaimana di definisikan "Doing Data Warehouse $(D W)$ to your business or system is not only think about the trend only, but how to understand the DW knowledge itself and how to implement it" [14]. Dan bagaimana cara mengukurnya "Measures are a standard unit used to express the size, amount, or degree of something, qualities are often difficult to be measured as it needs to have some certain parameter or elements, and those parameters must be quantifiable and verifiable" [15].

\subsection{Diagram HIPO}

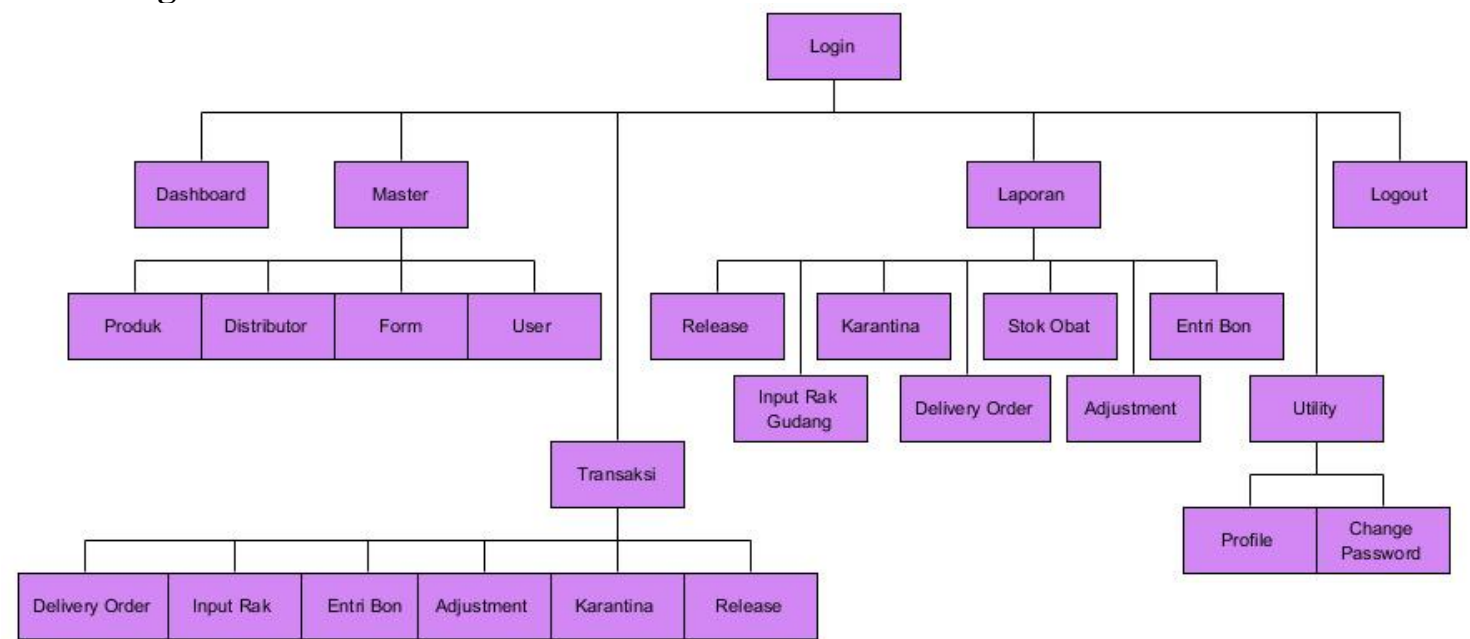

Gambar 7. HIPO

Untuk menggambarkan stuktur menu dari sistem yang dirancang dapat digambarkan dengan diagram HIPO (Hierarchy Input Process Output).Untuk menyediakan suatu struktur guna memahami fungsi-fungsi dari program.Terlihat dari diagram HIPO diatas (gambar 7) terdapat 1 (satu) fungsi utama (digram 0) dan 3 (tiga) fungsi dibawahnya, yaitu fungsi menu master (diagram 1), menu transaksi (diagram 2) dan menu report (diagram 3). Didalam fungsi menu master (diagram 1) terdapat 3 (tiga) fungsi sub menu yaitu fungsi menu pengelolaan data user (diagram 1.1), pengelolaan data suplier (diagram 1.2) dan pengelolaan data barang (diagram 1.3). Didalam fungsi menu transaksi (diagram 2) terdapat 4 (empat) fungsi fungsi sub menu yaitu fungsi menu pengelolaan data po (diagram 2.1), pengelolaan data surat jalan 
(diagram 2.2), pengelolaan data invoice (diagram 2.3) dan pengelolaan data tanda terima invoice (diagram 2.4). Didalam fungsi report (diagram 3) terdapat 4 (empat) fungsi sub menu yaitu fungsi menu pengelolaan data tagihan supplier (diagram 4.1), pengelolaan jatuh tempo hutang (diagram 4.2), pengelolaan presentasi jatuh tempo (diagram 4.3) dan pengelolaan data estimasi pembayaran (diagram 3.4).

\subsection{Rancangan Tampilan}

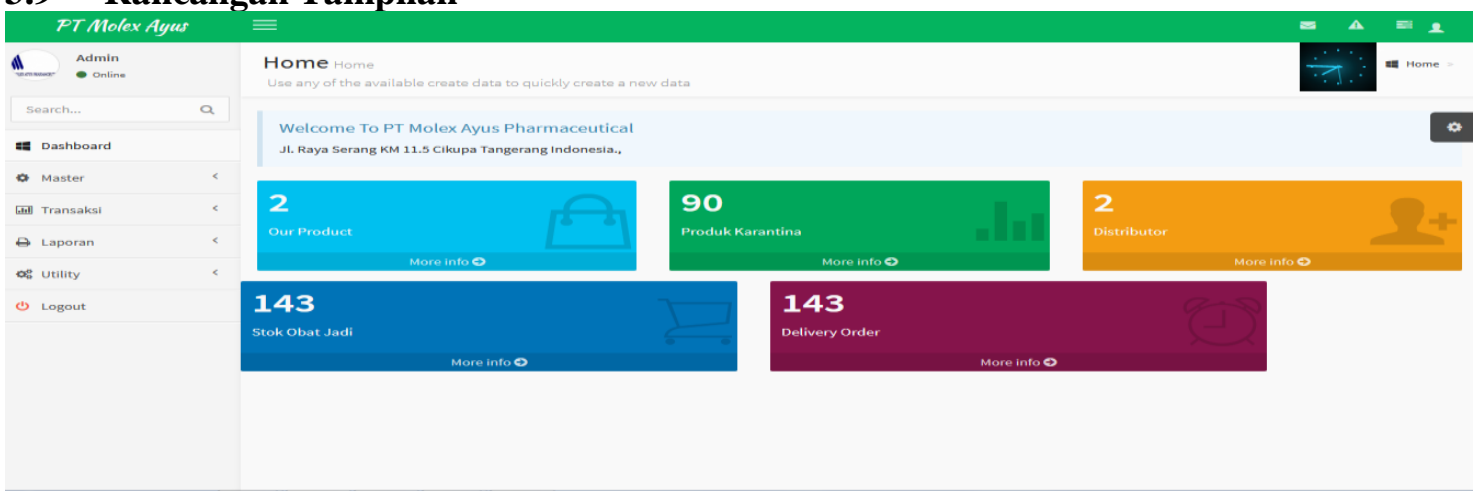

Gambar 8 Rancangan Layar Dasboard

Terlihat pada tampilan layar diatas (gambar 8) merupakan tampilan layar utama yang terdiri dari menu master, menu transaksi dan menu laporan.

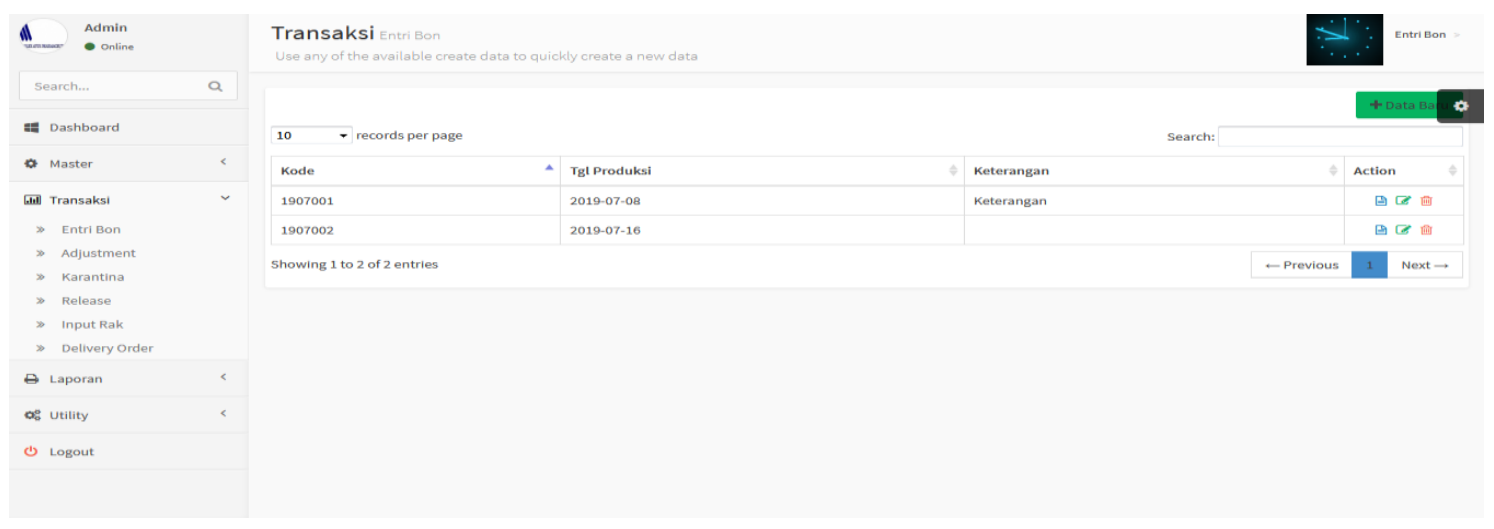

Gambar 9 Rancangan Layar Utama

Terlihat pada tampilan layar diatas (gambar 9) merupakan tampilan layar utama yang terdiri dari menu master, menu transaksi dan menu laporan, dimana menu transaksi memiliki sub menu entri bon, adjustment, karantina, release, input rak gudang, dan delivery order. 


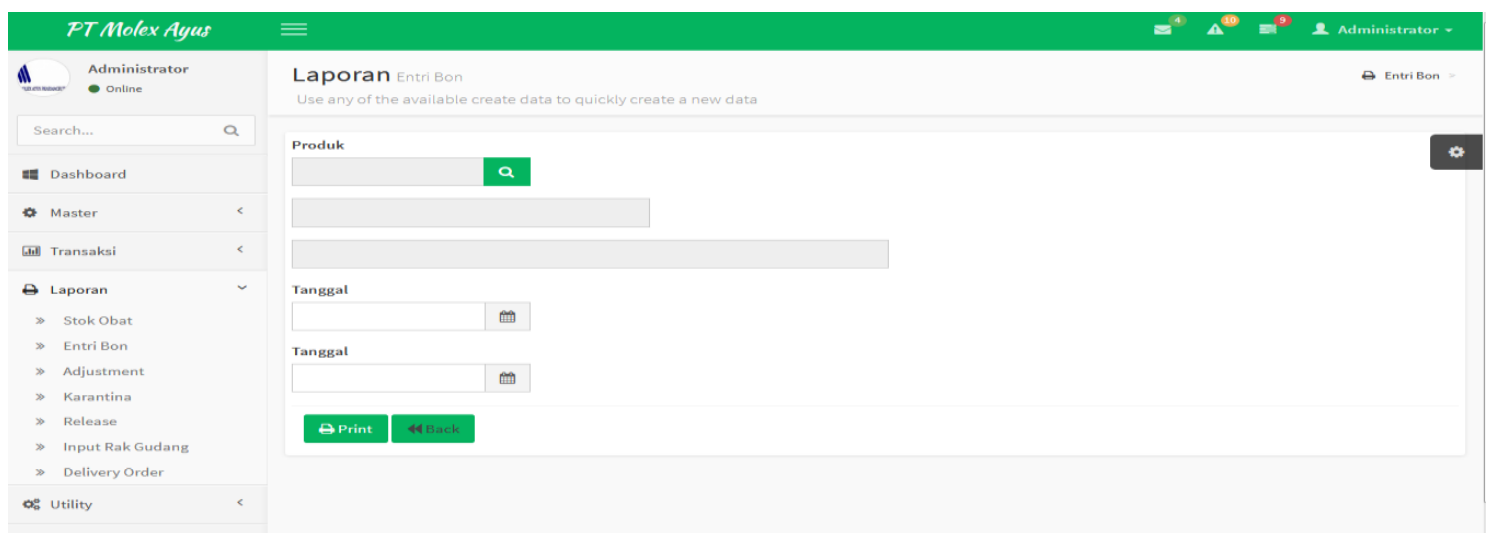

Gambar 10 Rancangan Layar Transaksi

Terlihat pada tampilan layar diatas (gambar 10) merupakan tampilan layar utama yang terdiri dari menu master, menu transaksi dan menu laporan, dimana menu laporanmemiliki sub menu stokobat, entri bon, adjustment, karantina, release, input rakgudang, delivery order

\subsection{Query Penciptaan Informasi Query function list_entri_bon:}

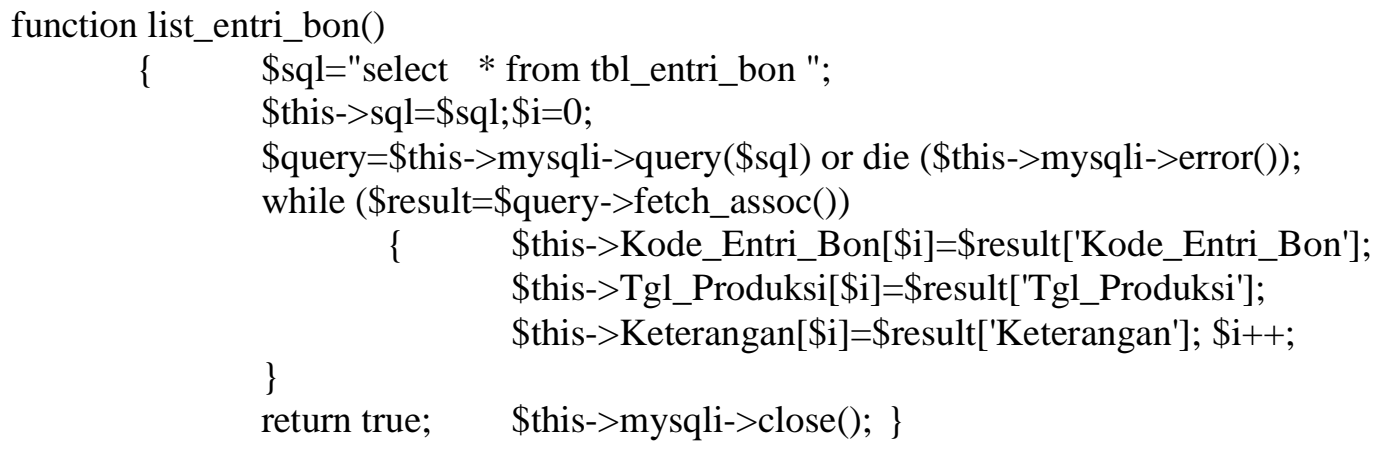

\section{Query Menciptakan Laporan Presentasi Jatuh Tempo:}

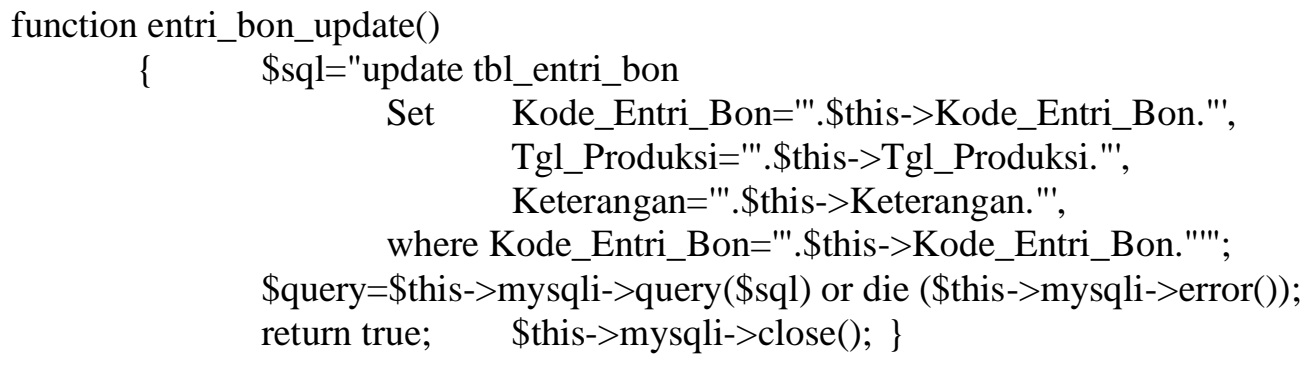

\section{KESIMPULAN}

Berdasarkan hasil analisa dari rumusan masalah yang telah dilakukan, dapat disimpulkan bahwa sistem distribusi obat yang berjalan saat ini masih menggunakan aplikasi manual dimana dalam pengelolaan datanya memakan waktu yang lama sehingga berdampak pada lamanya penyajian laporan serta adanya beberapa kesalahan yang menyebabkan ketidak akuratan. Tingginya tingkat manualisasi dalam sistem distribusi obat ini akan berakibat pada distribusi obat hasil produksi yang akan menurunkan kualitas dan menurunkan tingkat pelayanan kepada pelanggan. Untuk mengatasi semua ini, diperlukan sistem yang dapat menghasilkan laporan 
sistem distribusi obat yang cepat dan akurat, sehingga tidak ada lagi keterlambatan atau kesalahan dalam penginputan data obat maupun laporan data obat. Hal ini dapat dicapat dengan menggunakan beberapa metode penyelesaian seperti menggunakan uml untuk menggabarkan rancangan sistem, MySql untuk pengolahan basis data dan php sebagai bahasa pemrograman.

\section{SARAN}

Adapun saran yang dapat diberikan peneliti sebagai gambaran untuk mengatasi pemecahan masalah yang terjadi pada sistem distribusi obat antara lain :

1. Sistem distribusi obat yang belum terkomputerisasi sebaiknya segera direalisasikan agar sistem yang berjalan bisa segera terintegrasi dengan baik.

2. Membuat sistem distribusi obat yang dapat mempermudahkan proses pencarian datadata penting sehingga bisa menghemat waktu yang mungkin kita pergunakan untuk mencari data tersebut.

3. Pada pengembangan sistem distribusi obat ini diharapkan partisipasi dari PT Molex Ayus Pharmaceutical untuk memberikan dukungan agar dengan itu sistem ini dapat berjalan dengan baik

\section{DAFTAR PUSTAKA}

[1] Junaidi, J., Roji, A., \& Munawar, K. (2015). Konsep Otomatisasi Sistem Pembayaran SPP Online Untuk Mengurangi Tingkat Keterlambatan. Proceedings Konferensi Nasional Sistem dan Informatika (KNS\&I).

[2] Lestari, Endang. 2009. Analisa Sistem Pendukung Keputusan Untuk Proses Kenaikan Jabatan pada PT. X, Jurnal Sistem Informasi, 1, 141-150.

[3] Junaidi, T. K. Y. N. D. (2013). Sistem Pakar Monitoring Inventory Control Untuk Menghitung Harga Jual Efektif Dalam Meningkatkan Keuntungan. Yogyakarta: Universitas Ahmad Dahlan.

[4] Purwanti, Endang. 2008. Assesment Pembelajaran SD. Jakarta : Depdiknas.

[5] Junaidi, J., Effendy, M. Y., \& Hartono, H. (2015). REKAYASA MODEL APLIKASI SISTEM PRODUCT KNOWLADGE UNTUK MENDUKUNG PENGAMBILAN KEPUTUSAN DALAM MENENTUKAN KINERJA KARYAWAN. CERITA Journal, 1(1), 46-55.

[6] Henderi, H., Junaidi, J., \& Kusuma, T. A. H. (2012). Dashboard Monitoring System Penjualan Dan Reward Mobile Kios PT. Telekomunikasi Seluler. Semantik, 2(1).

[7] Junaidi, J., Arifin, R., \& Septiani, A. (2015). Rancang Bangun Aplikasi Sistem Inventory Berbasis Desktop Menggunakan JSE. Proceedings Konferensi Nasional Sistem dan Informatika (KNS\&I).

[8] Hidayat, Wahyu, Riri Mahmuriyah, dan Sri Ndayani Ratna Safitri. 2016. Media Visual Berbentuk Katalog Produk Sebagai Media Promosi. ISSN: 2461-1409. Jurnal SENSI Vol.2 No. 2-Agustus 2016. Tangerang : Perguruan Tinggi Raharja.

[10] Asbar, Yuli, dan Mochamad Ari Saptari. 2017. "Analisa Dalam Mengukur Kualitas Pelayanan Terhadap Kepuasan Konsumen Menggunakan Metode PIECES". Jurnal Visioner \& Strategis Vol. 6 Nomor 2, September 2017: 39-47 Universitas Malikussaleh. 
[11] Junaidi, J., Santoso, S., \& Sunarya, L. (2008). Rekayasa Teknik Pemrograman Pencegahan Dan Perlindungan Dari Virus Lokal Menggunakan API Visual Basic. CCIT Journal, 1(2), 134-153.

[12] Martono, A., \& Junaidi, D. Y. IMULATION GAME BASED ON JARIMAGIC METHOD TO CALCULATE MORE QUICKLY FOR ELEMENTARY STUDENTS.

[13] Junaidi, J., Cholisoh, N., \& Hasanah, N. (2018). Rancang Bangun Sistem Manajemen Aset IT Untuk Pencatatan History Maintenance Sebagai Pendukung Keputusan. SENSI Journal, 4(2), 220-231.

[14] M. Subekti, Warnars Junaidi, H.L.H.S., Y. Heryadi, "The 3 steps of best data warehouse model design with leaning implementation for sales transaction in franchise restaurant", Cybernetics and Computational Intelligence (CyberneticsCom) 2017 IEEE International Conference on, 20-22 Nov 2017.

[15] J. Junaidi, A. Julianto, N. Anwar, S. Safrizal, H.L.H.S. Warnars, K. Hashimoto, "Perfecting a Video Game with Game Metrics", Telkomnika, vol. 16, no. 3, pp. 13241331, June 2018

[16] Zainuddin, A., Junaidi, J., \& Putra, R. D. (2017). Design of E-Commerce Payment System at Tokopedia Online Shopping Site. Aptisi Transactions On Management, 1(2), 143-155.

[17] Junaidi, J., Sutrisno, S., \& Janah, K. (2019). MODEL APLIKASI PURCHASING SYSTEM UNTUK MONITORING STOK DALAM MENGURANGI TINGKAT KERUGIAN. SENSI Journal, 5(1), 86-98.

[18] AMALIA, Riski, et al. PEMODELAN APLIKASI INTEGRATED LEARNING SYSTEM BERBASIS MOBILE. SEMNASTEKNOMEDIA ONLINE, 2013, 1.1: 20-45.

[19] Henderi, H., Nuraeni, Y., Junaidi, J., \& Hidayat, R. (2010). IT GOVERNANCE: A STRATEGIC ALIGNMENT FOR INFORMATION TECHNOLOGY/BUSINESS. CCIT Journal, 4(1), 57-69.

[20] Junaidi, J., Alfiah, F., Susanti, E., Kristinna, J., Ardiansyah, O. R., Pradipta, D., \& Wulaningsih, W. (2015). MANFAAT MENGANALISIS PENGARUH SOSIAL MEDIA FACEBOOK TERHADAP KAMPANYE PARTAI POLITIK DI INDONESIA. SEMNASTEKNOMEDIA ONLINE, 3(1), 4-5. 